\title{
Higher Education in Developing Countries: Peril and Promise, a Decade and a Half Later: Development Lost?
}

\author{
Tor Halvorsen
}

\begin{abstract}
The author of this article argues that the Task Force behind the Peril and Promise report created a document that represents a silent compromise between what he calls "UNESCO values" and what is seen as "World Bank values." In the years after the report was written, development has been mostly shaped by WB values. The question is raised whether this is partly due to a weakening of UNESCO as an oppositional force to the hegemonic trend of neoliberalism and academic capitalism.

In conclusion, the article advocates that we need to opt again for a development of universities based on UNESCO values. We have to engage in an analytical evaluation of the present hegemony of academic capitalism, and argue more strongly for the alternative: higher education and research as part of culture and the public space, and as a precondition for strengthening democracy through academic freedom.
\end{abstract}

L'auteur de l'article soutient que le Groupe de Travail responsable du rapport « Périls et Promesses » a réalisé un document qui représente un compromis tacite entre ce qu'il appelle "les valeurs de l'UNESCO" et ce que l'on considère comme "les valeurs de la Banque mondiale". Dans les années qui ont suivi la publication du rapport, le développement a été principalement influencé par les valeurs de la Banque mondiale. La question posée ici est de savoir si ceci serait dû en partie à un affaiblissement de l'UNESCO en tant que force d'opposition à l'hégémonie croissante du néolibéralisme et du capitalisme académique.

En conclusion, l'article préconise de remettre les valeurs de l'UNESCO 
à la base du développement des universités. Il faut entreprendre un examen analytique de l'hégémonie actuelle du capitalisme académique, et soutenir plus vigoureusement le modèle alternatif : l'enseignement supérieur et la recherche comme parties intégrantes de la culture et de l'espace public, et comme condition préalable au renforcement de la démocratie par le biais de la liberté académique.

\section{Introduction}

In the years since the publication of the report Higher Education in Developing Countries: Peril and Promise in 2000, cooperation between the United Nations Educational, Scientific and Cultural Organization (UNESCO) and the World Bank (WB), has more or less dissolved. As argued by Richard Münch (20II) and experienced by most of us, if formally UNESCO is supposed to hold the global ministry of higher education, it is in reality the WB that now hosts this position.

The transformation of the WB's attitude into support for research and higher education development, expressed in the report, has of course been highly praised by most actors. The closer collaboration with UNESCO, the coproducer of the report, has also been taken as an important step toward change. As we will argue, this collaboration seems in retrospect to reflect a shift in policy within UNESCO, as a result of its weakness.

Our purpose is not, however, to debate the important shift within the WB, but rather what it has meant for science and science-based education. That the global organization for culture allied itself with an organization whose goal has been the promotion of academic capitalism throughout the world calls for reflection, so many years after the apparent alliance of the two multilateral organizations.

The questions we ask are: what made UNESCO the junior partner in the formulation of values and goals in this report? What are the consequences for "public knowledge," to which higher education and science are supposed to contribute, according to UNESCO values?

UNESCO seems to have become less and less visible on the global scene, particularly after its World Global Conference on Higher Education in Paris in 2009. On the contrary, the WB, in particular through its recent "centers of excellence" initiative, has transformed itself into an actor with direct influence on how knowledge institutions are organized in developing countries. As we know, this initiative is doomed to fail (see for example P. Altbach's comment: https://www. insidehighered.com/blogs/world-view/world-bank's-africa-initiativeforgetting-faculty).

The question is: why did this happen, given the fact that the two organizations, one created to promote culture, in particular education as culture, and the other to drive the global economic development as a knowledge economy, hardly found a workable compromise in their promotion of knowledge for development? The answer is simple. The report builds on a shallow reflection about how to reconcile these conflicting values: there is no proper debate on how they relate, and how they could, and should relate in times of economic globalization. As both J. Kocka (20I6) and C. Crouch (20I6) show, global capitalism, in our neoliberal times, undermines what we could call "UNESCO values." The role of knowledge for democracy (democracy being constituted within nation-states) has decreased since 2000. The lack of debate about conflicting values can be seen as a prelude to the later development toward academic capitalism, within the broader neoliberal revolution.

\section{Neoliberalism}

The 2000 report was written when the WB felt that its economic reasoning had become a global truism. About eight of the foremost neoliberal (mostly US) economists had received the Swedish State Bank Prize in economics (in honor of Alfred Nobel, contrary to the wishes of the Nobel family) (Mirowski 2004, 20I3). Most of them were members of the Mont Pélerin Society (MPS) created by F. Hayek, with friends, in 1947 (Plehwe, Neuhöffer, and Walpen 2008; Mirowski and Plehwe 2009). This was a think tank that gradually gained great influence on all Western institutions concerned with economic development, including the WB. One example of great importance is the infamous "Washington Consensus," which became the guidelines for development policies. In the mid-ig8os, these guidelines influenced all policy areas, also higher education and research. They were written by a prominent member of the MPS, and fitted well with the general neoliberal policy now also expanding to the global scene. During the I990s, a platform for "global economic development," to which developing countries had to adjust, was established, and served as a guide for the WB when the report on higher education was written.

But this neoliberal conformity also means a revised understanding of basic institutions of society. The liberal approach, where the market means exchange (between willing actors) and the role of the state is to secure the "natural human desire" (in the language of Adam Smith) to "exchange," the general neoliberal idea is that human improvements only happen through competition of one sort or the other, and the role of the state is to secure that this competition takes place. Competition is best, but not only, promoted by the market, which now is no longer 
defined by exchange between equals, but by strategies and power, or by "market-like" behavior, as in New Public Management, where contracts between management (principal) and those who do the jobs (agents) are built up around competitive elements (best practice comparisons to create benchmarks to compete against, means-ends measurements linked to rewards, blaming and naming of winners and losers, etc.)

The essence of neoliberalism-combining different traditions: German Ordoliberalism, Friedman's monetarism, and Buchanan's "public economy" (Schmidt and Thatcher 20I3) -is that the state is important for capitalist economy. Without a strong state, based on legality, one will not be able to:

a) Install a competitive element in all social organizations (only if we compete, do we improve). Markets and market-like structures promote competition the most, but both need the state to be established and to function.

b) Protect the laws of the economy from democracy or "mass influence." In this understanding of the economy, universities are seen as "infrastructure": state supported institutions promoting the economy.

The state must draw a dividing line between politics and the economy; a demarcation between spheres that democratic policies will easily overstep, if not kept in check. The state must create economic actors, while avoiding being itself an economic actor.

The point is: only a university driven by the realities of competition will install in academic staff and students a "competitive habitus" and make them alert to the realities of the market, from which they are too sheltered in public universities.

Why this reminder about neoliberalism? When the WB was writing its contribution to the Peril and Promise report, it was at the same time acting as a think tank on the burning issue of how to transform universities in parts of the world where it had influence (through its policy of lending), in line with neoliberal ideas. Its deliberations about why universities were again important, resulted toward the end of the previous century also in a new understanding of the role of the state, in line with what is discussed above. The state was to be one funder among many of a university competing for resources and justifying it existence through success on the market for knowledge services (see in particular the I997 WB report The State in a Changing World).

Neoliberalism is a policy developed within networks of thinkers, politicians, and media people, first of all (as indicated above) within the think tank MPS. There is a growing literature on the role of this think tank, both for defining and framing what "neoliberalism" is (Mirowski and Plehwe 2009). Later, others like the Atlas Network and the Stockholm Network have evolved from the MPS and its activists. Over their 70 years of existence, they have been spreading the gospel worldwide. Since MPS is limited to rooo members, its influence was not in numbers, but in the quality of the arguments. Many of these members, and others strongly influenced by this "Society," initiated new neoliberal think tanks. There is documentation on how MPS members took control of economics departments at universities, also in Africa.

Over the years, so-called development policies were on the agenda; the Washington Consensus became one of MPS' greater successes, and constitutes to this day a set of guidelines for WB policies in most developing countries, only recently coming under criticism.

Already in the early I990s, WB demanded that countries, particularly in Africa, open up for private providers, or seek as much as possible to privatize public universities. The transformation in Africa was well underway in 2000 , when the report was written. Today, the number of so-called universities has multiplied (Cloete et al, 20I5), showing that the market for educational services works.

Another important idea of the WB group of neoliberal thinkers was that science and education needed to be much more differentiated. In particular, research was spread around too much. A global transformation of the economy needed a concentration of resources around "big projects" relevant for innovative shifts. Competition had to be global, therefore the WB, with the help of state power if necessary, needed to differentiate the market: there should no longer be any "national system," rather, universities should become specialist in certain fields and seek support for "excellent" knowledge in these fields globally. Universities should develop centers of excellence to attract the best students and academic staff. That the WB was encouraging a potential, state-supported, type of oligopoly did not cross the minds of the Task Force behind the 2000 report. The "excellence hype" exploded all over the world, also in Africa, where the WB now funds the African Higher Education Centers of Excellence Project (http://www.worldbank.org/en/search?q=The+ex cellence+initiative+of+Africa).

What I refer to as "the UNESCO values," are values that are dependent on the nation-state protection of public spaces. The WB, on the other hand, want these public spaces to be transformed into an arena of competing actors whose identification might be local, national, or global, or a combination of these, according to what competitive strategy they develop. The state should not be an "owner" of spaces of public knowledge development, but rather a "contract partner," and in this contract-relation it should develop competitive elements: result- 
oriented goals, and a system of evaluation that pushes the competitive elements. Universities have to deliver to their funders, including the state (most often the biggest funder), underdelivery should be punished, and contracts dissolved if other competing universities-also from abroad-deliver better service. Internationalization is needed to make competition the key element of the university sector, a sector traditionally used to being part of a "public space" dependent on state funding.

\section{WB: New Strength through Self-Criticism}

Neoliberalism generally weakened UNESCO's influence and how we value knowledge, science, and culture. It was a great boost for the WB. It was therefore no big risk to let the Task Force openly criticize the Bank and its previous policy on higher education, according to which higher education (unlike school education) does not bring a return to public investments: developing countries should rather use the global market for higher education services (from the West) (on the I985 WB arguments for this, see Mamdani 2007).

The 2000 report reflected what seemed to be a dramatic shift in the policy of the WB, from traditional liberalism to neoliberalism. As argued above, the state has again a role to play in promoting economic development as part(ner) of the "governance" of different competing sectors of society, and secondly, the global economy is a "knowledge economy," driven by research and science-based knowledge and education.

This global economy, according to the report, is a given, to which all have to adjust in order not to be left behind (see also Accelerating Catchup-Tertiary education for growth in Sub-Saharan Africa, WB 2009).

\section{The Shallow Compromise of 2000}

While the WB became the advocate of the "knowledge economy" and strongly supported what was later called "academic capitalism" (see in particular R. Münch, 20II), UNESCO kept promoting knowledge as culture, as part of development seen as a nation-state responsibility. While the WB started referring to Chile and Senegal, for example, as "economies," UNESCO around 2000 was still referring to cultures, nations, identities, and improved well-being through general access to knowledge.

The report does not try to unite these positions at a conceptual level. It represents a kind of hybrid, neoliberal discourse trying to make public organizations and institutions act as if they are part of a marketplace or "public economy." This hybridity, or mixed discourse, was not only theoretical, but reflected also hybrid practices among universi- ties, and spread gradually to most universities throughout the world (Maassen and Olsen 2008). The values of the WB and neoliberalism, however, seemed to have the upper hand, transforming the collegial university into a "stakeholder" university (Bleiklie and Kogan 2007), and knowledge institutions into service providers.

Despite reference to Philip Altbach's throughgoing influence on the work of the Task Force and in shaping up the text, the document is not consistent. With hindsight, the influence of UNESCO back then seems to have been stronger than what we could expect today. In other words, the text confirms the decline of UNESCO's ideas and values, and the continued pressure of the WB for its own strategy of shaping knowledge institutions for its model of development. Neoliberalism has succeeded, among other reasons, thanks to WB policies.

This is different from functionalist theories, according to which a university seeks to serve many goals and actors at the same time. The university is an organization of contradictory goals competing for resources, attention, and leadership decisions. In this perspective, goals are being pursued at different times, by different divisions or offices, so that value conflicts rarely undermine the institutional values of the university as played out on the public scene (Cloete et al. 20I5). The focus here is rather on how values transform.

\section{A Bewildering Mixture of Texts and Thoughts-or How to Write Reports in Times of Shifting Values}

If we go into the detail of the textual composition, semantics, and rhetoric of the report, it seems that representatives of the two organizations have been responsible for different paragraphs, chapters, even the summaries of these chapters, and different parts of the conclusion.

Where the WB shows influence, we read that universities are important for linking on to the global economy and for developing human capital. It is argued that universities need funding from a variety of sources, due to limitations on public spending. The space for the state is where there is "market failure," thus a need for a system that is planed in a way to promote competition between different academic units. STEM (Science, Technology, Engineering, and Mathematics) disciplines need to be prioritized-without any reference to how these disciplines depend on the humanities (see Higgins 2013) - as well as good management, within the frame of good governance. The role of the state is contested, so is the space for private universities, but both can be handled with good "intermediate" organizations (like quality assurance agencies), with delegated state authority, and ruling through principal-agent kinds of contracts and control. 
A closer look at the "UNESCO parts" of the report shows a stronger emphasis on words like citizens development, the role of knowledge for democracy, the importance of faculty, staff, and the academic profession, the need for a wider, system-based focus based on planning and long-term ideas about nation-state development, on cooperation (as a value in its own right, but also important to moderate competition), public interests, nation-state and national leadership, and public value beyond private return.

And with nuanced reading, we also find inconsistencies, mirroring the values of the two organizations, in their view of the state and of what governance means-a category that has become part of the neoliberal project.

Unfortunately, the idea that the global economy is there as a given, as a constant, is uncontested in the report. If we cant development, we have to adjust to it. This is, however, where we find the biggest internal contradiction in the report. The Task Force argues strongly (and in line with what I call "UNESCO values") that it does not want to impose its recommendations on nation-state "cultures and variations": we are all different for good reasons, and it is this difference that must be valued, not challenged, for example by global economic demands. The report, therefore, only wants to point to some common values. These may take many shapes according to cultural embeddedness. Examples of common values are academic freedom and the need for long-term financing (to allow academic planning, job security, and a stable framework for the academic leadership). These recommendations may be of use for the actors of the different national cultures, to go from where they are to where they should be as a knowledge society.

Where they should be is, however, clear for the WB, which promotes economic globalization. Developing countries must link on to the now extremely liberalized global economy, even to the point where external investments are prioritized over internal investments, both legally and politically (Gill and Cutler 20I4). Thus, nation-states and their particular cultures (developing valuable human variations) are seen as "economies" that have to become "knowledge economies" in order to be able to develop.

\section{Management and Human Capital vs. Academic Leadership and \\ Citizenship}

How shallow and unreflective the compromise between the two multilateral organizations was in 2000 , is best seen through the semantics: on the one hand, we have "management and human capital," on the other "academic leadership and citizenship." These two expressions stand in stark contrast to one another and describe two different kinds of universities.

If the report had tried to theorize more around these categories and show what they imply for our understanding of knowledge in society, it probably would not have been written as one document.

Since then, however, we cannot find one single document from the WB that does not argue that the "product" of universities is "high quality human capital," preferably graduated from STEM disciplines. It is human capital development, not education for citizenship, that now penetrates the strategic documents of all universities that try to become leading in the competition for rankings. As noted by Salim Badat (Halvorsen and Vale 20I2), education for citizenship and democracy is for the festive speeches of vice-chancellors.

In 2000 , the report had a whole chapter dedicated to the value of general (or liberal) education, arguing that this kind of knowledge, in addition to developing citizenship, had a crucial role for the economy-since it made humans creative. If, as current brain research shows, body and mind are linked in the most intricate manner, creating a variety of cultural expressions, then liberal knowledge may also be most useful for the economy, as long as the economy promotes creativity and is not obsessed by "linking on to the global economy" (Berg and Seeber 20I6). To "link on to the global economy" is a very weak appeal to anything but instrumentality and "human capital," and leaves no room for the value of cultural variations. In the report, there is no attempt to theorize these things. Rather, the report seems almost apologetic about its belief in the value of "liberal education," although the value of democracy and of "the role of knowledge for democracy" is commonly acknowledged. Nowadays, we hardly see UNESCO defending these important values on the public scene any more. It is the WB STEM orientation within so-called centers of excellence, semidetached from the life of universities, that puts its mark on higher education in Africa.

But to understand the deeper consequences of the schism between education of human capital vs. citizenship and democracy, we have to look at two other categories: management vs. academic leadership.

\section{Keeping Order on the University Playground}

The introduction of the report has the twist of the WB language:

"The Task Force has concluded that, without more and better higher education, developing countries will find it increasingly difficult to benefit from the global knowledge-based economy" (Task Force p.9).

And then at the end, we get to know what the writers of the report 
really believe prevents this development from coming through:

"[...] poor management is often the single greatest obstacle to stronger higher education." (Task Force p.88)

While the report as a whole refers to faculty as a collegial collective and to the quality of the scientists as crucial for growth, and assures us that without good academics there is no good university, it still concludes, paradoxically, that the problem is "management."

Given the many passages in the report holding forth the importance of giving to faculty the conditions necessary to do their job (proper wages, equipment, long-term working conditions, and good collegial relations), we still do not find any reference to ways of granting enough power to the academic profession itself, in order to secure such working conditions. There are no suggestions as to how faculty could collectively increase their influence and the quality of their teaching through research and scholarship: neither at the level of the university, through governance reforms promoting democracy, nor at the societal level, by supporting professional unions. Rather, the Task Force ends by saying that strong leadership is good, therefore vice-chancellors should be hired instead of elected as "first among equals." Without reference to any supporting literature, strong leadership is presented as a leadership hired by actors more or less external to the university, but with the idea that they are "stakeholders" in it.

This understanding of the academic profession as employed in organizations in need of strong leadership (like private companies) is turned into a mantra by the WB, and unfortunately rarely contested by UNESCO, an organization that should know better. The word "strong" is neither clarified nor defined. Both "strong" and "leadership" are underexplained, yet supported in Africa and beyond, and in the report seem to have undermined academic freedom as a precondition for the development of good faculty. In other words, over the years the WB idea of leadership — as management of market-like organizations-has gradually undermined the strength of the academic profession. The overall impression is that the report justifies this degradation, despite its occasional reference to the quality and social status of the faculty.

And while faculty are prevented by "strong leadership" from controlling their own means of academic creativity, they end up in a subordinate position, which—according to WB reasoning_only good management can release them from.

Why is this degradation possible, and why has the WB "cashed in" this victory so systematically in the following years?

In order for a university to contribute with human capital production, as input to a workforce striving to link the local economy to the global economy, then so-called "proper management" is necessary to steer the input of the faculty.

"Human capital" is a product of neoliberal intellectuals (see Becker I964, a prominent member of the neoliberal think tank MPS, see above). So are also the management techniques to make faculty governable. What good management consists of is only hinted at in the report, and academic collaboration between academics still has a value, together with competition between university organizations.

But in the following years, the WB bought increasingly into the kind of management that now is promoting competition at all levels, also among public cultural institutions, for the sake of efficiency. What counts is "stakeholder universities," organizational management, reputation building, organizational (not academic) rankings, ratings, and rewards. With the right management, even an African university can get on to the ranking lists.

If we focus on democracy, citizenship, and enlightened decisionmaking as a societal good (which are important in the report, but have vanished later), it is not management that is the problem, but the social status of faculty. To strengthen this status means not only to strengthen the belief in academic knowledge among all social actors, but also to support the effort of academics to gain power over their own workplace, the university, and their profession.

But, as indicated, this has not happened. And the WB is not alone in promoting managerial control. As the report edited by Johann Mouton and Lauren Wildschut on "Leadership \& Management" (2015) show, a great number of funders have given support to management development, seen as the key to solving all ills. In my view, there are many that are misled by the idea that "strong leadership" is important. Much of this focus on management has undermined what, according to the report itself (when referring to cultural variation), sees as a precondition for "a good university": the academic freedom of faculty to develop their commitment to their own knowledge, ideas, and interests.

Today we have better studies on university leadership and on the relation between academic freedom and management. A publication (so far available only in Swedish) written by experienced university leaders Kerstin Sahlin and Ulla Eriksson-Zetterquist: Collegiality-A Modern Form of Governing (Kollegialitet-En moderne styrform), shows that a "strong faculty," which also governs the university, is a far better kind of governance than "management" and managerialism, and that many of the arguments against democratic universities have little hold in reality. They are primarily part of the neoliberal discourse about how New Public Management must work, rather than contributing to the 
common goal of creating good knowledge, both for the economy and for democracy. As the authors argue, reflecting on the academic and democratic governance of the university also forces us to constantly discuss the very purpose the university (p. I70): what role knowledge should have in our society and our organizations.

In this perspective, general (or liberal) education matters also. Universities promoted by the WB focus on "human capital"-thus on STEM disciplines-act as instruments without the need for language (Higgins 20I3). Higgins develops an alternative acronym, NAIL, standing for Narrative, Analysis, Interpretation, Literature. The same way mathematics is a common language for STEM, literature/language is common for NAIL. But what is more important: NAIL is a precondition for STEM at all levels. Engineers need NAIL knowledge to be able to conceive and comprehend both how to make technology and how engineers and technology impact society. "No economy can come right or approach anything like optimal performance levels without the skills and understanding that research and training in the humanities and social sciences can provide" (Higgins p.I77).

As Wendy Brown (p.I64) shows, this lack of understanding of these links between types of knowledge undermines also the link between knowledge and democracy: "As it [the "WB" university] devotes itself to enhancing the value of human capital, it now abjures the project of producing a public readied for participation in popular sovereignty" (see in particular chapter VI "Educating Human Capital”).

\section{The Case of Makerere University}

The report contains numerous references to cases, but these are mere examples of points made in the text, or illustrations to press a point, without any analysis.

Makerere University receives special attention. It is used as an example that confirms many of the developments the report-the "WB" part of the report-wishes to see. A university in crisis, reinventing itself, among other things, through public/private initiatives: evening schools increasing the number of students; giving a better pay to the academics; making use of the market for educational services, etc., measures that altogether also give the university better funding. Public/private mobilization of resources and a gradual reduction of all traditional privileges for students, like public stipends, housing, and food, have the potential to transform students into customers on an equal basis - if they can pay the costs of study.

When the report was published, Makerere University was, according to WB rhetoric, on its way to renewed glory. Today, it is closed due to unrest and mismanagement, corruption, and political attempts to increase control. In spite of much support, and participation in all the management courses for higher education Africa offered the last 20 years, its management has failed miserably. Clearly, more management courses - still the solution pushed by the WB-are not the answer.

The answer to the problems of Makerere University and similar universities in Africa lies elsewhere. A book by Mahmood Mamdani, Scholars in the Marketplace (2006), gives a different picture. The author is foreseeing the crisis of today: a management seen as instrumental in recreating the university is corrupted both by income and power. The academics are reduced to student-throughput teachers. Professor Mamdani suggests that the university may now be called, at best, a glorified high school, and scholars and scholarship now operate on a marketplace. Time and money for research are vanishing. Only donor funding keeps research and research-based knowledge going.

Mamdani argues that it is not the creativity of management that has transformed Makerere University (as the Peril and Promise report indicates), but rather "good governance" advice from the WB. The "human capital" approach leads to a lowering of qualifications to "just past the post" in a labor market that should be served by vocational education. And worst of all: proper liberal education deteriorates.

Mamdani's book, through its penetrating analysis and the concrete suggestions for change came to influence the political life of Makerere University. The collective moonlighting enriching some, but undermining the university infrastructure and most of all the quality and self-respect of the faculty, was discontinued as a consequence of his academic intervention.

But the idea of a managerially run university is there to stay. Administration keeps growing, academic posts are kept vacant. Today, management is the biggest threat to the university, and no training or administrative techniques can change that. Makerere University is the best, but by far not the only, example of how wrong the Task Force was in its belief-or rather, how wrong it was that the WB assumed the hegemony by interpreting the ideals and ideas from this report for future support to universities as part of its broader, neoliberal development strategy.

\section{Summary and Conclusion}

To summarize: after diagnosing the ills of the university sector, the report informs us that the cure is better management under a leadership with more space for autonomous decision-making.

It is the WB ideas that have pushed development. In this polity, 
universities have to be decoupled from state control so as to become strategic actors within what sometimes is called the market for educational services, other times the global competition for knowledge resources (OECD 2004, Kelsey 2006, Halvorsen and Nyhagen 2006 , 2005). And they need to have "freedom" to focus, to serve specific clients (not society in general or the public), thus to be able to specialize so as to meet the needs of actors in the global economy. And they need to search for the best brains, reputed professors, and resources and projects that bring overhead to the organization. To do this, "management" becomes the key resource, professors the junior partners, so-called "managed personnel."

Such a cure is perhaps relevant for academic capitalism, but has proven to be rather contradictory to the growth of knowledge in societies at large-the public knowledge project. The voice of UNESCO is barely heard as defender of science and science-based education (the $\mathrm{S}$ and the $\mathrm{E}$ in its acronym) as public goods. Knowledge as culture, which emphasizes the role of academics, has lost out to knowledge as a product or as "functional capital," mediated by "knowledge brokers" (management and its leadership) to actors in society who put a prize on these knowledge results, or, as N. Cloete et al. argue, outputs of a "production" process. Human capital, research results, relevance for the economy, knowledge for innovations, trade in educational services; all of this receives more attention from the WB than the processes of knowledge development within a cultural and social community, what once upon a time was called by Humboldt "Bildung zur wissen."

It is to the use of these governance instruments the report became such an impetus and legitimating force. There is today an abundance of quality assurance for academic work, types of evaluation, ratings, rankings, numerically based instruments for measuring efficiency (from citation indexes to publication statistics). But, in our view, it is rather the exponential growth of management at universities, making itself influential with the help of all these governance instruments, that needs to be evaluated. What is needed is quality assurance for university management, a part not even mentioned in the Peril and Promise report, based on the values of public knowledge as opposed to the values of academic capitalism. In other words, we suggest that UNESCO takes back its role in the global public space.

To conclude: the Task Force was born with a split personality; the WB and UNESCO were forced together by the global community. Neoliberal "medication" keeps the UNESCO personality at bay, letting WB narcissism blossom. It is time to let the other "personality" back on the stage. So far we only see development lost. Unfortunately, UNESCO has been victimized over the years by the instrumentalism of human capital ideology, and ideas that competition is the best way to develop capabilities and organizational capacities. All else leads to corruption or corrupt behavior, ego trips and rent seeking. And competition needs to be managed by a management itself governed by competition.

It is now time to test, as Wendy Brown and Kerstin Sahlin also suggests, the truism of the neoliberal university. What knowledge does it deliver? What are we losing when all focus is on human capital and management?

If UNESCO cannot write the next report, actors committed to UNESCO should be invited. International Association of Universities (IAU) is one of them, which also reflects properly on the role of universities in the Anthropocene age (Halvorsen 20I5). The WB has had its time. It is worth repeating the words of D. Teferra: "Africa is a vast continent of abundant cultures, values, and languages whose futures appear to be uncertain as the forces of globalization are sweeping and market forces are unduly glamorized. There are more than thousand languages spoken. Nigeria, the most populous country on the continent alone counts for more than 350 languages." (Teferra 2005:289)

Maybe this is a reality we should try to "link on to" in our future reforms of higher education for development. Perhaps then we can "catch up"?

\section{References}

Becker, Gary (1994). Human Capital: A theoretical and empirical analysis with special reference to Education. Chicago: The University of Chicago Press.

Berg, Maggie and Barbara K. Seeber (20I6). The Slow Professor. Challenging the Culture of Speed in the Academy. Toronto: University of Toronto Press.

Bleiklie, Ivar and Maurice Kogan (2007). Organisation and Governance of Universities. Higher Education Policy 20: 477 - 493.

Brown, Wendy (20I5). Undoing the Demos. Neoliberalism's Stealth Revolution. New York: Zone Books.

Crouch, Colin (2016). The Knowledge Corrupters. Hidden Consequences of the Financial Takeover of Public Life. Cambridge: Polity Press.

Cloete, Nico, Peter Maassen and Tracy Bailey (20I5). Knowledge Production, Contradictory Functions in African Higher Education. Cape Town: African Minds.

Fourcarde-Gourinchas, Marion and Sarah L. Babb (2002). The Rebirth of the Liberal Creed: Paths to Neoliberalism in Four Countries. 
American Journal of Sociology. Volume Io8, Number 3 (November 20002). 533-79.

Gill, Stephen and A.Claire Cutler (20I4). New Constitutionalism and World Order. Cambridge: Cambridge University Press.

Hall, Peter A. and Michèle Lamont (2009). Successful Societies. How Institutions and Culture Affect Health. Cambridge: Cambridge University Press.

Halvorsen, Tor and Peter Vale (eds.) (20I2). One World. Many Knowledges. Cape Town: African Minds and SANORD.

Halvorsen, Tor, Hilde Ibsen, and Vyvienne PR M' kumbuzi (eds) (20I5). Knowledge for a Sustainable World. A Southern African-Nordic Contribution. Cape Town: African Minds and SANORD.

Halvorsen, Tor and Atle Nyhagen (2006). Towards a New Contract between Universities and Society. A historical sociological perspective on the Lisbon Strategy and EU policies on higher education and research. Bergen: University of Bergen publ.

Halvorsen, Tor and Atle Nyhagen (2005). The Bologna Process and the Shaping of the Future Knowledge Societies. Bergen: University of Bergen publ.

Higgins, John (2013) Academic Freedom. Essays and Interviews on Higher Education and the Humanities. Johannesburg: Wits University Press.

Kelsey, Jane (2005). Taking Minds to Markets. In: Halvorsen, Tor and Atle Nyhagen (2006). Towards a New Contract between Universities and Society. A historical sociological perspective on the Lisbon Strategy and EU policies on higher education and research. Bergen: University of Bergen publ.

Kocka, Jürgen (20I6). Capitalism. A Short History. Princeton: Princeton University Press.

Maassen, Peter and Johan P. Olsen (eds) (2007). University Dynamics and European Integration. Dordrecht: Springer Verlag.

Mamdani, Mamoud (2007). Scholars in the Marketplace. Dakar: CODESRIA book series.

Mirowski, Philip and Dieter Plehwe (2009). The Road from Mont Pélerin. The Making of the Neoliberal Thought Collective. Cambridge: Harvard University Press.

Mirowski, Philip (2013). Never Let a Serious Crisis Go to Waste. How neoliberalism survived the financial meltdown. London: Verso.

Mirowski, Philip (2004). The Effortless Economy of Science. Durham: Duke University Press.

Mouton, Johann and Lauren Wildschut (2015). Leadership and Management. Case studies in training in higher education in Africa. Cape
Town: African Minds.

Münch, Richard (20II). Akademischer Kapitalismus Über die politische ökonomie der Hochschulereform. Berlin: Suhrkamp.

Teferra, Damtew (2005). The Bologna Process. The experiences-and challenges-for Africa. In: Halvorsen, Tor and Atle Nyhagen (2005). The Bologna Process and the Shaping of the Future Knowledge Societies. Bergen: University of Bergen publ.

The Task Force on Higher Education and Society (2000). Higher Education in Developing Countries. Peril and Promise. Washington: The World Bank printer (for the Task Force).

Plehwe, Dieter, Gisela Neunhöffer, and Berhard Walpen (2006). Neoliberal Hegemony. A Global Critic. London: Routledge.

Sahlin, Kerstin and Ulla Eriksson-Zetterquist (20I6). Kollegialitet. En moderne styrform. Lund: Studentlitteratur.

Schmidt, Vivian A. and Mark Thatcher (20I3). Resilient Liberalism in Europe's Political Economy. Cambridge: Cambridge University Press.

World Bank (1997). The State in a Changing World. World Development Report. Washington: World Bank.

World Bank (2009). Accelerating Catch-up-Tertiary Education for Growth in sub-Saharan Africa. Washington: World Bank. 